\title{
Penerapan Teknik Konseling Eklektif dengan Perilaku Attending dalam Pemecahan Masalah Hubungan Interpersonal
}

\author{
Made Sukri* \\ SMP Negeri 6 Singaraja, Singaraja-Bali
}

A R T I C L E I N F O

Article history:

Received 20 May 2019

Received in revised form

16 June 2019

Accepted 30 July 2019

Available online 29

August 2019

Kata Kunci:

Bimbingan Konseling,

Eklektif, Attending,

Interpersonal

Keywords:

Counseling Guidance,

Eclective, Attending,

Interpersonal

\begin{abstract}
A B S T R A K
Jenis penelitian ini adalah penelitian tindakan bimbingan konseling (PTBK). Subyek penelitian ini adalah siswa kelas VIII B2 SMP Negeri 6 Singaraja Semester Genap Tahun Pelajaran 2018/2019 berjumlah 32 orang dengan rincian 16 laki-laki dan 16 perempuan. Obyek penelitian ini adalah hubungan interpersonal siswa kelas VIII B2. Variabel dalam penelitian ini adalah konseling eklektif dan hubungan interpersonal siswa kelas VIII B2. Instrumen penelitian ini adalah angket sosiometri. Data yang telah terkumpul dianalsis secara deskriptif. Simpulan dari hasil penelitian ini adalah (1) Ada 4 bentuk hubungan interpersonal pada data awal dan siklus I, yaitu kelompok I, II, III, dan IV. (2) Dengan teknik konseling eklektif dengan perilaku attending, dapat mengubah bentuk hubungan interpersonal siswa kelas VIII B2 SMP Negeri 6 Singaraja dimana pada data awal dan siklus I terbentuk 4 kelompok selanjutnya pada siklus II menjadi 3 kelompok. (3) Dengan konseling eklektif dengan perilaku attending dapat menurunkan jumlah siswa yang mengalami penolakan/tidak disukai; dan (4) Dengan konseling eklektif dengan perilaku attending dapat meningkatkan jumlah siswa yang diterima di dalam hubungan interpersonal pada siswa kelas VIII B2 SMP Negeri 6 Singaraja.
\end{abstract}

\section{A B S T R A C T}

The kind of this research is counseling action research. The subjects of this study were class VIII B2 SMP Negeri 6 Singaraja Even Semester, 2018/2019 Academic Year totaling 32 people with details of 16 men and 16 women. The object of this research is the interpersonal relations of class VIII B2 students. The variables in this study were eclective counseling and interpersonal relations of class VIII B2 students. The instrument of this study was a sociometric questionnaire. Data that has been collected is analyzed descriptively. The conclusions from the results of this study are (1) There are 4 forms of interpersonal relationships in the initial data and the first cycle, namely groups I, II, III, and IV. (2) With the eclective counseling technique with attending behavior, it can change the form of interpersonal relations between class VIII B2 SMP Negeri 6 Singaraja, where in the initial data and cycle I 4 groups are formed in the second cycle into 3 groups. (3) With eclective counseling with attending behavior can reduce the number of students who experience rejection / dislike; and (4) With eclective counseling with attending behavior can increase the number of students accepted in interpersonal relationships in class VIII B2 SMP Negeri 6 Singaraja. 


\section{Pendahuluan}

Hasil penelitian yang dilakukan oleh Sukri $(2018,2019)$ tentang penerapan konseling eklektif dengan perilaku attending untuk mengatasi permasalahan dan peningkatan prestasi belajar IPA pada siswa kelas VIII B2 tahun pelajaran 2018/2019 SMP Negeri 6 Singaraja dapat disimpulkan bahwa (1) Dengan menggunakan teknik konseling eklektif dengan perilaku attending dapat mengatasi permasalahan belajar siswa dalam mata pelajaran IPA; (2) Dengan teknik konseling eklektif dengan perilaku attending dapat meningkatkan prestasi/hasil belajar siswa dalam mata pelajaran IPA. Dari hasil penelitian tersebut, dapat disimak bahwa penerapan konseling eklektif dengan perilaku attending dapat digunakan untuk memecahkan masalah belajar dan dapat meningkatkan prestasi belajar IPA. Suatu situasi yang ada di kelas, khususnya di kelas VIII B2 SMP Negeri 6 Singaraja menunjukkan adanya hubungan sosial atau hubungan interpersonal yang kurang harmonis. Kekurangharmoniasan itu terlihat dari indikasi adanya siswa yang kurang diterima oleh teman-teman lainnya dalam sosiometri. Ada sejumlah siswa yang ditolak dalam gambaran sosiometri. Ada kurang lebih enam orang siswa yang ditolak dalam pendataan sosiometri yang telah diakukan oleh peneliti sendiri sebagai studi pendahuluan. Dari data yang ada, ada sebanyak enam orang siswa ditolak dalam hubungan sosial kelas dengan jumlahr penolakan 5-17. Artinya siswa ini dalam hubungan sosialnya ditolak oleh teman-teman sebanyak 5-17 orang.

Hasil wawancara dengan beberapa siswa di kelas tersebut, ada beberapa alasan yang menjadi bahan penolakan terhadap hubungan sosial yang terjadi di antara siswa seperti (1) siswa yang bersangkutan terlalu nakal, (2) siswa tersebut sebagai sumber keributan, (3) siswa tersebut suka menfitnah, (4) siswa itu dipandang sombong, (5) siswa itu sering super acting, (6) siswa itu dipandang sering mencari muka kepada guru. Banyak hal yang menjadi alasan ditolak/diterima siswa itu dalam pergaulan di kelas.

Rumiyati (2019) menyatakan bahwa sosiometri mengukur hubungan interpersonal antara siswa dalam suatu kelas. Tujuan dari sosiometri adalah untuk mengukur nilai sosial individual dari seseorang yang diketahui dari teman-temannya. Sosiometri memberikan informasi peranan siswa di dalam kelas dan dapat berguna untuk menelusuri permasalahan hubungan sosial dengan teman-teman sekelasnya. Dari pengetahuan tentang sosiometri tersebut dapat diketahui permasalahan hubungan sosial antara siswa satu dengan siswa lainnya di kelas tersebut. Dari data pendahuluan yang terkumpul, tampak bahwa ada permasalahan dalam hubungan interpersonal di kelas tersebut. Oleh karenanya perlu dilakukan penelitian tindakan bimbingan konseling (PTBK) untuk memecahkan masalah tersebut.

Keberadaan Bimbingan dan Konseling di sekolah memberikan dampak positif yang amat besar terhadap perkembangan pendidikan dan pribadi siswa, hal ini mengingat banyaknya permasalahan belajar yang dialami siswa (Ahmadi, dkk, 2004).Penanganan masalah-masalah siswa di atas dalam kerangka bimbingan dan konseling diselesaikan melalui konseling individu maupun konseling kelompok. Berbagai teori dikemukakan oleh para ahli mengenai pendekatan atau teknik yang digunakan oleh konselor ketika proses konseling berlangsung. Pada dasarnya pendekatan/teknik konseling itu dibagi tiga (Surya: 1988) yaitu: teknik konseling direktif, non-direktif dan Eklektif. Teknik Konseling Eklektif merupakan penggabungan dua teknik Konseling Direktif dan Non Direktif. Peneliti memadukan kebaikan/kelebihan dua teknik konseling tersebut, mengembangkan dan menerapkan dalam praktek sesuai dengan permasalahan hubungan interpersonal yang dialami siswa Kelas VIII B2 SMP Negeri 6 Singaraja. Berkenaan dengan hal tersebut rumusan masalah dalam penelitian ini adalah (1) Bagaimanakah bentuk hubungan interpersonal di antara siswa kelas VIII B2 SMP Negeri 6 Singaraja? (2) Apakah dengan teknik konseling eklektif dengan perilaku attending, dapat mengubah bentuk hubungan interpersonal siswa kelas VIII B2 SMP Negeri 6 Singaraja? (3) Apakah dengan konseling eklektif dengan perilaku attending dapat menurunkan jumlah siswa yang mengalami penolakan di dalam hubungan interpersonal pada siswa kelas VIII B2 SMP Negeri 6 Singaraja. (4) Apakah dengan konseling eklektif dengan perilaku attending dapat meningkatkan jumlah siswa yang diterima di dalam hubungan interpersonal pada siswa kelas VIII B2 SMP Negeri 6 Singaraja.

\section{Metode}

Jenis penelitian ini adalah jenis penelitian tindakan bimbingan konseling (PTBK). Subyek penelitian ini adalah siswa kelas VIII B2 SMP Negeri 6 Singaraja Semester Genap Tahun Pelajaran 2018/2019 berjumlah 32 orang (16 laki-laki dan 16 perempuan). Obyek penelitian ini adalah hubungan interpersonal siswa kelas VIII B2. Variabel dalam penelitian ini adalah konseling eklektif dan hubungan interpersonal siswa kelas VIII B2.

Konseling ini akan dilaksanakan melalui tahap-tahap sebagai berikut: (a) Layanan informasi, (b) Memberikan arahan, (c) Menentukan tindakan, (d) Melaksanakan tindakan, (e) Evaluasi, (f) Refleksi 


\section{Siklus 1}

Untuk mendapatkan data hubungan interpersonal sisiwa kelas VIII B2, digunakan instrument sosiometri. Adapun langkah-langkah yang dilakukan adalah sebagai berikut: (a) Persiapan meliputi (1) Menentukan kelas siswa yang diselidiki, (2) Memberikan informasi tertentu tentang tujuan diselenggarakannya sosiometri. (3) Mempersiapkan angket sosiometri kartu pilihan sosiometri, (4) Pelaksanaan meliputi: (1) Membagikan dan mengisi angket sosiometri, (2) Mengumpulkan kembali dan memeriksa apakah pengisian angket sudah benar. Analisis Hasil meliputi (1) Langkah-langkah dilakukan dalam analisis hasil sosiometri, yaitu: (a) Memeriksa hasil angket sosiometri, (b) Mengadakan tabulasi dan membuat matrik sosiometri, (c) Membuat sosiogram, (d) Membuat indeks pemilihan yakni indeks pemilihan dibuat dengan rumus: i.p. = Jumlah yang memilih_rumus: $\quad$ ip $=(n-1) \_k e t e r a n g a n ~ i . p=$ indeks pemilihan_n = jumla anggota dalam kelompok_Membuat laporan hasil analisis sosiometri. Hasil yang diperoleh dari tindakan ini selanjutnya digunakan sebagai bahan refleksi1.

\section{Siklus 2}

Pada siklus 2 dilaksanakan atas dasar bahan refleksi 1. Bila dalam pembinaan konseling eklektif dengan perilaku attending masih ada jumlah yang tidak disukai belum ada perubahan yang meyakinkan, maka dibuatkan perencanaan tindakan dan pelaksanaan tindakan ke-2 berupa penyempurnaan bimbingan konseling eklektif attending yang dilengkapi dengan pengamatan/observasi di saat jam istirahat di kelas, layanan informal, dan memberikan konseling secara klasikal dan individual secara langsung. Selanjutnya dilakukan observasi, refleksi dan evaluasi. Dalam penelitian ini hanya dibatasi pada dua siklus karena keterbatasan biaya, tenaga dan waktu. Data yang telah dikumpulkan, selanjutnya dianalisis sesuai dengan jenis data yang diperoleh. Data yang berkaitan dengan hubugan interpersonal, alasan yang diberikan,dan peranan bimbingan konseling eklektif dengan perilaku attending yang diterapkan,dianalisissecaradeskriptif.

\section{Hasil dan Pembahasan}

Dari hasil angket sosiometri yang disebarkan kepada siswa, disajikan pada Tabel 1.

Tabel 1. Data Hasil Studi Awal Sosiometri Siswa Kelas VIII B2 SMP Negeri 6 Singaraja

\begin{tabular}{|c|c|c|c|c|c|}
\hline \multirow{2}{*}{ NO } & \multirow{2}{*}{ Nomor Absen } & \multicolumn{2}{|c|}{ Yang Menyukai } & \multicolumn{2}{|c|}{ Yang Menolak } \\
\hline & & Jumlah Siswa & Indeks Penerimaan & Jumlah Siswa & Indeks Penolakan \\
\hline 1. & 1. & 3 & 0,09 & 0 & 0,0 \\
\hline 2. & 2. & 3 & 0,09 & 0 & 0,0 \\
\hline 3. & 3. & 2 & 0,06 & 0 & 0,0 \\
\hline 4. & 4. & 3 & 0,09 & 0 & 0,0 \\
\hline 5. & 5. & 6 & 0,19 & 0 & 0,0 \\
\hline 6. & 6. & 2 & 0,06 & 0 & 0,0 \\
\hline 7. & 7. & 1 & 0,03 & 1 & 0,0 \\
\hline 8. & 8. & 4 & 0,12 & 3 & 0,09 \\
\hline 9. & 9. & 1 & 0,03 & 0 & 0,00 \\
\hline 10. & 10. & 0 & 0,0 & 0 & 0,00 \\
\hline 11. & 11. & 0 & 0,00 & 10 & 0,32 \\
\hline 12. & 12. & 2 & 0,06 & 2 & 0,06 \\
\hline 13. & 13. & 3 & 0,09 & 2 & 0,06 \\
\hline 14. & 14. & 7 & 0,22 & 3 & 0,09 \\
\hline 15. & 15. & 0 & 0,00 & 9 & 0,29 \\
\hline 16. & 16. & 1 & 0,03 & 1 & 0,03 \\
\hline 17. & 17. & 3 & 0,09 & 2 & 0,06 \\
\hline 18. & 18. & 2 & 0,06 & 2 & 0,06 \\
\hline 19. & 19. & 1 & 0,03 & 0 & 0,00 \\
\hline 20. & 20. & 0 & 0,00 & 0 & 0,00 \\
\hline 21. & 21. & 5 & 0,16 & 3 & 0,09 \\
\hline 22. & 22. & 0 & 0,00 & 11 & 0,35 \\
\hline 23. & 23. & 0 & 0,00 & 2 & 0,06 \\
\hline 24. & 24. & 2 & 0,06 & 0 & 0,00 \\
\hline 25. & 25. & 0 & 0,00 & 5 & 0,16 \\
\hline 26. & 26. & 2 & 0,06 & 5 & 0,16 \\
\hline 27. & 27. & 1 & 0,03 & 0 & 0,00 \\
\hline 28. & 28. & 2 & 0,06 & 0 & 0,00 \\
\hline
\end{tabular}




\begin{tabular}{cccccc}
\hline \multirow{2}{*}{ NO } & \multirow{2}{*}{ Nomor Absen } & \multicolumn{2}{c}{ Yang Menyukai } & \multicolumn{2}{c}{ Yang Menolak } \\
& & Jumlah Siswa & Indeks Penerimaan & Jumlah Siswa & Indeks Penolakan \\
\hline 29. & 29. & 0 & 0,00 & 0 & 0,00 \\
30. & 30. & 2 & 0,06 & 3 & 0,09 \\
31. & 31. & 0 & 0,00 & 0 & 0,00 \\
32. & 32. & 3 & 0,09 & 0 & 0,00 \\
\hline
\end{tabular}

Berdasarkan Tabel 1 tampak bahwa hubungan interpersonal siswa kelas VIII B2 dapat dikategorikan menjadi 4 (empat) kelompok yakni: (1) Kelompok I yaitu siswa yang disukai saja dan tidak ada siswa yang menyatakan yang tidak menyukai/menolak (untuk penjelasan berikutnya, lebih sederhananya digunkan istilah menurut peneliti: banyak teman dan tidak ada musuh); artinya siswa ini tergolong punya banyak teman dan tidak punya "musuh" (ditolak) . (2) Kelompok II adalah siswa yang disukai dan sekaligus ada yang tidak menyukai/menolak; artinya kelompok ini punya teman dan sekaligus punya "musuh" (punya teman dan punya musuh). (3) Kelompok III adalah siswa yang tidak dipilih disukai tetapi hanya ditolak/tidak disukai; Artinya kelompok ini tidak punya teman tetapi punya "musuh" (tidak punya teman tetapi punya musuh). dan (4) Kelompok IV adalah siswa yang tidak dipilih disukai dan sekaligus tidak dipilih tidak disukai. Artinya kelompok ini tidak dipilih sebagai teman dan tidak dipilih juga sebagai "musuh" (tidak punya teman dan juga tidak punya musuh).

Jumlah siswa dari kelompok I ada sebanyak 12 orang (37,5\%). Kelompok II ada sebanyak 11 orang $(34,38 \%)$. Kelompok III ada sebanyak 5 orang (15,63\%). Kelompok IV ada sebanyak 4 orang $(12,5 \%)$. Alasan-alasan yang diberikan/dipilih pada saat mereka memilih teman yang disukai berturutturut adalah Suka Membantu sebanyak 25 orang, Kelakuan Baik (25 orang), Pandai (20 orang), Jujur (19 orang), Rajin (15 orang), dan Berteman Akrab Sejak Lama. Sedangkan untuk alasan menolak berturutturut adalah Pemalas (25 orang), Kelakuan Tidak Baik (22 orang), Cepat Tersinggung (16 orang), Kurang Pandai (12 orang), Egois (12 orang), Sering Berbohong (9 orang), Sering Memfitnah (6 orang), dan Bermusuhan Sejak Lama (0 orang). Bila kita tetapkan 4 alasan yang dipilih dengan nilai yang lebih dari $50 \%$ dari jumlah siswa maka alasan untuk memilih sebagai teman adalah suka membantu, berkelakuan baik, pandai dan jujur. Sedangkan untuk menolak siswa untuk tidak diajak berteman adalah dengan alasan pemalas, kelakuannya tidak baik, cepat tersinggung, dan kurang pandai.

Dengan mengetahui hasil sosiometri dan alasan-alasan utama yang dijadikan untuk kriteria memilih teman dan menolak teman pada siswa kelas VIII B2 ini, maka lebih lanjut digunakan sebagai langkah dalam memberikan konseling yaitu konseling eklektif dengan perilaku attending. Untuk konseling klasikal ditekankan pada etika pergaulan dan sekaligus memberikan arahan peningkatan hubungan interpersonal sesuai dengan pilihan yang disediakan pada angket sosiometri seperti: a). kejujuran , b) kepandaian, c) murah senyum, d) suka membantu, e) keobjektifan, f) rajin, g) berkelakuan baik, dan h) pertemanan. Demikian juga terkait dengan sikap-sikap yang harus diperhatikan agar tidak ditolak oleh teman-teman dalam pergaulan sehari-hari seperti: a) berbohong, b) kurang pandai, c) cepat tersinggung, d) keegoisan, e) sering memfitnah, f) pemalas, g) kelakuan tidak baik, dan h) permusuhan.

Tindakan I, melakukan layanan konseling dengan bimbingan individu dan klasikal dengan tetap berorientasi pada bimbingan konseling ekliktif attending (mencari solusi atas masalah yang dihadapi oleh siswa, di mana siswa sebagai pusat gagasannya untuk menyampaikan solusinya, dan guru BK bersifat sebagai penyempurna atau tambahan solusi, melalui kontak mata, badan, bahasa lisan guru BK yang menimbulkan rasa nyaman bagi siswa/klien).

Observasi

Setelah selesai melakukan konseling eklektif dengan perilaku attending secara individual dan klasikal, selanjutnya dilakukan pengamatan/observasi terhadap hubungan interpersonal yang terjadi. Hasil pengumpulan data dengan angket sosiometri ini disajikan pada Tabel 2.

Tabel 2. Data Hasil Studi Siklus I Sosiometri Siswa Kelas VIII B2 SMP Negeri 6 Singaraja

\begin{tabular}{ccccccc}
\hline \multirow{2}{*}{ No } & \multirow{2}{*}{ Nomor Absen } & \multicolumn{2}{c}{ Yang Menyukai } & \multicolumn{2}{c}{ Yang Menolak } \\
\cline { 3 - 6 } & & Jumlah Siswa & Indeks Penerimaan & Jumlah Siswa & Indeks Penolakan \\
\hline 1. & 1. & 2 & 0,06 & 0 & 0,00 \\
2. & 2. & 6 & 0,19 & 1 & 0,03 \\
3. & 3. & 2 & 0,06 & 0 & 0,00 \\
4. & 4. & 2 & 0,06 & 0 & 0,00 \\
5. & 5. & 3 & 0,09 & 1 & 0,03 \\
6. & 6. & 1 & 0,03 & 1 & 0,03 \\
\hline
\end{tabular}




\begin{tabular}{cccccc}
\hline \multirow{2}{*}{ No } & \multirow{2}{*}{ Nomor Absen } & \multicolumn{2}{c}{ Yang Menyukai } & \multicolumn{3}{c}{ Yang Menolak } \\
& Jumlah Siswa & Indeks Penerimaan & Jumlah Siswa & Indeks Penolakan \\
\hline 7. & 7. & 2 & 0,06 & 1 & 0,03 \\
8. & 8. & 1 & 0,03 & 4 & 0,12 \\
9. & 9. & 1 & 0,03 & 0 & 0,00 \\
10. & 10. & 1 & 0,03 & 0 & 0,00 \\
11. & 11. & 0 & 0,00 & 3 & 0,09 \\
12. & 12. & 2 & 0,06 & 0 & 0,00 \\
13. & 13. & 2 & 0,06 & 5 & 0,16 \\
14. & 14. & 4 & 0,12 & 1 & 0,03 \\
15. & 15. & 2 & 0,06 & 9 & 0,29 \\
16. & 16. & 1 & 0,03 & 0 & 0,00 \\
17. & 17. & 2 & 0,86 & 2 & 0,06 \\
18. & 18. & 0 & 0,00 & 5 & 0,16 \\
19. & 19. & 3 & 0,09 & 0 & 0,00 \\
20. & 20. & 2 & 0,06 & 0 & 0,00 \\
21. & 21. & 4 & 0,12 & 7 & 0,22 \\
22. & 22. & 0 & 0,00 & 13 & 0,41 \\
23. & 23. & 1 & 0,03 & 8 & 0,00 \\
24. & 24. & 4 & 0,12 & 1 & 0,03 \\
25. & 25. & 1 & 0,03 & 6 & 0,19 \\
26. & 26. & 2 & 0,06 & 0 & 0,00 \\
27. & 27. & 2 & 0,06 & 1 & 0,01 \\
28. & 28. & 6 & 0,19 & 0 & 0,00 \\
29. & 29. & 2 & 0,06 & 1 & 0,03 \\
30. & 30. & 0 & 0,00 & 2 & 0,06 \\
31. & 31. & 0 & 0,00 & 0 & 0,00 \\
32. & 32. & 3 & 0,09 & 0 & 0,00 \\
\hline
\end{tabular}

Jumlah siswa dari kelompk I ada sebanyak 12 orang (37,5\%). Kelompok II 15 orang (46,88\%). Kelompok III 4 orang $(15,63 \%)$. Kelompok 1 orang $(12,5 \%)$. Untuk memperjelas perubahan persentase dari data awal sampai dengan siklus I disajikan pada Tabel 3.

Tabel 3. Perubahan Hubungan Interpersonal Dari data Awal ke Siklus I Siswa Kelas VIII B2 SMP Negeri 6 Singaraja

\begin{tabular}{ccccccl}
\hline N & Kelompok & \multicolumn{2}{c}{ Data Awal } & \multicolumn{2}{c}{ Siklus I } & \multirow{2}{*}{ Keterangan } \\
\cline { 3 - 6 } o & & Jumlah Anggota & $\%$ & Jumlah Anggota & $\%$ & \\
\hline 1 & I & 12 & 37,5 & 12 & 37,5 & Tetap \\
2 & II & 11 & $34,38 \%)$ & 15 & 46,88 & Meningkat $12,50 \%$ \\
3 & III & 5 & 15,63 & 4 & 12,5 & Menurun 3,13\% \\
4 & IV & 4 & 12,5 & 4 & 12,5 & Tetap \\
\hline
\end{tabular}

Kelompok I tidak terjadi perubahan persentase jumlah anggota. Pada kelompok II terjadi peningkatan persentase jumlah anggota (12,5\%). Pada kelompok III terjadi penurunan jumlah anggotanya $(3,13 \%)$. Kelompok I dan IV tidak terjadi perubahan. Terjadinya penurunan jumlah anggota dari masing-masing kelompok menunjukkan bahwa terjadinya perubahan yang lebih baik, di mana siswa yang awalnya tidak punya teman pada data awal, dan pada siklus I sudah memiliki teman. Sebagai refleksi dari siklus I dapat disimak keberhasilan dari konseling eklektif dengan perilaku attending pada siklus I yaitu: (1) Ada 7 orang siswa yang tetap berada pada kelompok I (2) Ada beberapa siswa yang telah berhasil merubah hubungan interpersonalnya dari awalnya berada pada kelompok II menjadi kelompok I (3) Diketahui terjadi hubungan interpersonal di antara siswa yang sangat dinamis, artinya hubungan interpersonal siswa mengalami perubahan yang sangat cepat dalam hal pergaulan sehari-hari.

Berdasarkan refleksi pada siklus I, maka dipandang penting untuk dilakukan tindakan ke siklus II. Pada siklus II ini merupakan perbaikan tindakan pada siklus I. Langkah-langkah yang ditempuh pada siklus II ditambah pada layanan inti berupa observasi dan layanan informal yang berlangsung di luar kelas pada saat jam istirahat. Observasi Hasil observasi pada siklus II disajikan pada Tabel 4. 
Tabel 4. Data Hasil Studi Siklus II Sosiometri Siswa Kelas VIII B2 SMP Negeri 6 Singaraja

\begin{tabular}{|c|c|c|c|c|c|}
\hline \multirow{2}{*}{ No } & \multirow{2}{*}{ Nomor Absen } & \multicolumn{2}{|c|}{ Yang Menyukai } & \multicolumn{2}{|c|}{ Yang Menolak } \\
\hline & & Jumlah Siswa & Indeks Penerimaan & Jumlah Siswa & Indeks Penolakan \\
\hline 1. & 1. & 3 & 0,09 & 1 & 0,03 \\
\hline 2. & 2. & 4 & 0,12 & 1 & 0,03 \\
\hline 3. & 3. & 2 & 0,06 & 2 & 0,06 \\
\hline 4. & 4. & 3 & 0,09 & 0 & 0,00 \\
\hline 5. & 5. & 6 & 0,19 & 2 & 0,06 \\
\hline 6. & 6. & 1 & 0,07 & 2 & 0,06 \\
\hline 7. & 7. & 2 & 0,06 & 1 & 0,03 \\
\hline 8. & 8. & 1 & 0,03 & 5 & 0,16 \\
\hline 9. & 9. & 1 & 0,03 & 1 & 0,03 \\
\hline 10. & 10. & 2 & 0,06 & 0 & 0,00 \\
\hline 11. & 11. & 1 & 0,03 & 4 & 0,12 \\
\hline 12. & 12. & 3 & 0,09 & 0 & 0,00 \\
\hline 13. & 13. & 2 & 0,06 & 0 & 0,00 \\
\hline 14. & 14. & 4 & 0,12 & 0 & 0,00 \\
\hline 15. & 15. & 1 & 0,03 & 17 & 0,54 \\
\hline 16. & 16. & 1 & 0,03 & 1 & 0,03 \\
\hline 17. & 17. & 2 & 0,06 & 0 & 0,00 \\
\hline 18. & 18. & 1 & 0,03 & 4 & 0,12 \\
\hline 19. & 19. & 1 & 0,03 & 0 & 0,00 \\
\hline 20. & 20. & 2 & 0,06 & 2 & 0,06 \\
\hline 21. & 21. & 2 & 0,06 & 2 & 0,06 \\
\hline 22. & 22. & 1 & 0,03 & 9 & 0,29 \\
\hline 23. & 23. & 0 & 0,00 & 0 & 0,00 \\
\hline 24. & 24. & 5 & 0,16 & 0 & 0,00 \\
\hline 25. & 25. & 1 & 0,03 & 7 & 0,22 \\
\hline 26. & 26. & 1 & 0,03 & 0 & 0,00 \\
\hline 27. & 27. & 3 & 0,09 & 0 & 0,00 \\
\hline 28. & 28. & 2 & 0,06 & 0 & 0,00 \\
\hline 29. & 29. & 1 & 0,03 & 0 & 0,00 \\
\hline 30. & 30. & 2 & 0,06 & 3 & 0,09 \\
\hline 31. & 31. & 0 & 0,00 & 0 & 0,00 \\
\hline 32. & 32. & 3 & 0,09 & 0 & 0,00 \\
\hline
\end{tabular}

Jumlah siswa dari kelompk I ada sebanyak 12 orang $(37,5 \%)$. Kelompok II 17 orang $(53,13 \%)$. Kelompok III sudah tidak muncul pada siklus II ini (0\%). Kelompok IV 2 orang $(6,25 \%)$. Untuk melihat persentase perubahan hubungan interpersonal antara siklus I dan siklus II disajikan pada Tabel 5.

Tabel 5. Perubahan Hubungan Interpersonal dari Siklus I ke Siklus II

\begin{tabular}{cclllll}
\multirow{2}{*}{ No } & \multirow{2}{*}{ Kelompok } & \multicolumn{2}{c}{ Siklus I } & \multicolumn{2}{c}{ Siklus Ii } & \multirow{2}{*}{ Keterangan } \\
\cline { 3 - 6 } & & Jumlah Anggota & $\%$ & Jumlah Anggota & \% & \\
\hline 1 & I & 12 & 37,5 & 12 & 37,5 & Tetap \\
2 & II & 15 & 46,88 & 17 & 53,13 & Meningkat 6,27\% \\
3 & III & 4 & 12,5 & 0 & 0 & Menurun 12,5\% \\
4 & IV & 4 & 12,5 & 2 & 6,25 & Menurun 6,25\% \\
\hline
\end{tabular}

Berdasarkan Tabel 5 terlihat Kelompok I menunjukkan tidak adanya perubahan. Kelompok ini adalah kelompok kategori populer. Kelompok II mengalami peningkatan jumlah anggota $(6,27 \%)$. Kelompok III sudah menurun secara drastis (0\%). Kelompok IV terjadi penurunan jumlah anggota (6,25\%). Kelompok ini termasuk kategori yang terisolir. Dengan pemberian konseling ekliktif dengan perilaku attending jumlah anggota yang terisolir menjadi semakin menurun.

Dari hasil penelitian tersebut dapat dinyatakan bahwa peran konseling kepada siswa sangat besar perannya dalam hal untuk membantu siswa dalam memecahkan masalah yang dihadapi. Hal ini sesuai dengan batasan dari bimbingan konseling itu sendiri yakni Bimbingan dan Konseling adalah pelayanan bantuan untuk peserta didik, baik secara perorangan maupun kelompok, agar mampu mandiri 
dan berkembang secara optimal, dalam bidang pengembangan kehidupan pribadi, kehidupan sosial, kemampuan belajar, dan perencanaan karir, melalui berbagai jenis layanan dan kegiatan pendukung, berdasarkan norma-norma yang berlaku. Demikian juga dilihat dari fungsi konseling yang relevan dengan hasil penelitian ini yakni (1) Pemahaman, yaitu fungsi untuk membantu peserta didik memahami diri dan lingkungannya. (2) Pencegahan, yaitu fungsi untuk membantu peserta didik mampu mencegah atau menghindarkan diri dari berbagai permasalahan yang dapat menghambat perkembangan dirinya. (3) Pengentasan, yaitu fungsi untuk membantu peserta didik mengatasi masalah yang dialaminya. (4) Pemeliharaan dan pengembangan, yaitu fungsi untuk membantu peserta didik memelihara dan menumbuh-kembangkan berbagai potensi dan kondisi positif yang dimilikinya. Dan (5) Advokasi, yaitu fungsi untuk membantu peserta didik memperoleh pembelaan atas hak dan atau kepentingannya yang kurang mendapat perhatian (Sukartini, 2003). Penerapan konseling eklektif yaitu merupakan penggabungan dua pendekatan Direktif dan Non-Direktif. Konseling eklektif yang mengambil berbagai kebaikan/kelebihan dari dua kebaikan/kelebihan dari dua pendekatan atau dari berbagai teori konseling, mengembangkan dan menerapkan dalam praktek sesuai dengan permasalahan klien. Konseling eklektif lebih tepat dan sesuai dengan filsafat tujuan bimbingan dan konseling dari pada sikap yang hanya mengandalkan satu pendekatan satu pendekatan atau satu dua teori tertentu saja (Surya, 1988).

Sebagaimana sudah disampaikan di atas bahwa perubahan hubungan interpersonal terjadi perubahan yang sangat dinamis. Hal ini sesuai dengan pendapat yang disampaikan oleh Yunita (2011), Ajeng (2012), dan Fathonah (2014) yang menyatakan bahwa dalam menjaga hubungan pertemanan terdapat banyak kejadian atau permasalahan yang muncul dalam hubungan pertemanan atau persahabatan. Yunita (2011) dan Septi (2013) menjelaskan bahwa kehidupan sosial remaja ditandai dengan menonjolnya fungsi intelektual dan emosional. Remaja sering mengalami sikap hubungan sosial yang tertutup sehubungan dengan masalah yang dialaminya. Menurut Erick Erison, bahwa masa remaja terjadi masa krisis, masa pencarian jati diri. Di samping itu dinyatakan bahwa kebutuhan remaja terhadap hubungan dengan teman sebaya sangatlah penting untuk perkembangan sosialnya (Santrock, 2007; Darajat, 2000).

Hasil penelitian ini relevan dengan penelitian yang dilakukan oleh Sukri $(2018,2019)$ yang menyatakan bahwa penerapan konseling ekliktif dengan perilaku attending dapat mengatasi masalahmasalah belajar dan meningkatkan prestasi belajar IPA. Hasil penelitian yang dilakukan oleh Wira dan Zaini (2017) menyimpulkan bahwa kemampuan interpersonal skill remaja perlu diidentifikasi sedini mungkin untuk meminimalisir dampak yang tidak diharapkan terjadi pada perkembangan selanjutnya, dan dalam rangka mengembangkan kemapuan sosial remaja. Hasil penelitian yang dilakukan oleh Hasanah (2018) terkait pemilihan kepala sekolah dengan menggunakan sosiometri sebagai instrument untuk mencari calon yang terpopuler menunjukkan hasil sebagai berikut. (a) Berdasarkan analisis sosiometri terdapat tiga orang guru yang berpotensi sebagai kepala sekolah. Hal ini ditunjukkan dengan banyaknya pemilih. (b) Berdasarkan hasil isian alasan pemilih angket sosiometri diperoleh kriteria kepala sekolah yang baik menurut kepala sekolah, guru dan staff di SD Negeri Puron 03, yaitu memiliki rasa percaya diri yang tinggi, kreatif dan inovatif, cepat tanggap dalam berbagai keadaan, menyelesaikan masalah dengan musyawarah, mengambil keputusan dengan arif dan bijaksana, memiliki dedikasi dan etos kerja yang tinggi, mampu menyesuaikan diri dengan keadaan dan aturan yang berubah-ubah, memiliki rasa tanggung jawab yang tinggi, dan senang membantu.

\section{Simpulan Dan Saran}

Dari hasil penelitian tindakan kelas bimbingan konseling (PTBK) ini, dapat disimpulkan: (1) Ada 4 bentuk hubungan interpersonal pada data awal dan siklus I yang terjadi pada siswa kelas VIII B2 SMP Negeri 6 Singaraja, yaitu kelompok I di mana kelompok ini termasuk siswa yang disukai dan tidak ada yang memilih untuk tidak disukai. Kelompok II yaitu kelompok yang termasuk siswa yang disukai dan sekaligus ada yang memilih tidak disukai. Kelompok III yaitu kelompok dengan siswa yang termasuk di dalamnya adalah siswa yang tidak dipilih untuk disukai, tetapi dipilih sebagai siswa yang tidak disukai. Kelompok IV adalah kelompok yang di dalamnya termasuk siswa yang tidak dipilih untuk disukai dan juga tidak dipilih untuk tidak disukai. Pada siklus II terjadi perubahan bentuk hubungan interpersonal yaitu hanya terbentuk 3 kelompok yakni kelompok I, kelompok II, dan kelompok IV. (2) Dengan teknik konseling eklektif dengan perilaku attending, dapat mengubah bentuk hubungan interpersonal siswa kelas VIII B2 SMP Negeri 6 Singaraja dimana pada data awal dan siklus I terbentuk 4 kelompok selanjutnya pada siklus II menjadi 3 kelompok. (3) Dengan konseling eklektif dengan perilaku attending dapat menurunkan jumlah siswa yang mengalami penolakan/tidak disukai di dalam hubungan interpersonal (sosio metri) pada siswa kelas VIII B2 SMP Negeri 6 Singaraja. Dari data awal ke siklus I terjadi penurunan pada kelompok III sebesar 3,13\%. Pada siklus I ke siklus II terjadi penurunan pada 
Kelompok III sebesar 12,5\% dan kelompok IV sebesar 6,25\%. Dan (5) Dengan konseling eklektif dengan perilaku attending dapat meningkatkan jumlah siswa yang diterima di dalam hubungan interpersonal (sosio metri) pada siswa kelas VIII B2 SMP Negeri 6 Singaraja. Dari data awal ke siklus I terjadi peningkatan pada Kelompok II sebesar 12,5\%.Dari Siklus I ke Siklus II pada Kelompok II terjadi peningkatan sebesar 6,27\%.

Dari simpulan di atas, ada beberapa saran yang dapat direkomendasikan yaitu: (1) Konseling yang dilakukan kepada siswa dengan menggunakan teknik eklektif attending sangat efektif untuk membantu memecahkan masalah hubungan interpersonal yang dihadapi siswa, oleh karenanya disarankan kepada guru-guru BK untuk dapat menerapkan teknik eklektif attending sebagai salah satu teknik untuk melakukan konseling.(2) Guru pemegang mata pelajaran dalam melaksanakan proses belajar mengajar di kelas, sebaiknya memperhatikan kondisi siswa terutama dalam hal hubungan interpersonal, di mana dalam hubungan interpersonal ini terjadi perubahan yang sangat dinamis, sehingga dalam memfonis siswa sebagai siswa yang bersifat negatif, tidak didasarkan pada satu kali pengamatan, tetapi dilakukan secara intensif dan berkelanjutan

\section{Daftar Rujukan}

Ajeng, Dhea. 2012. Indahnya Menjalin Hubungan Dengan Teman Sebaya. Diakses dari http://fauzulmunamunacantik.blogspot.com/2012/05/indahnya-menjalin-hubungan-dengan-teman.html. Diunduh pada 22 Maret 2019.

Daradjat zakiah. 2000. Remaja dan Harapan dan Tantangan. Jakarta: Ruhama.

Fathonah, Eytti. 2014. Etika Pergaulan Dengan Teman Sebaya. Diakses dari (http://www.scribd.com/doc/16176402/Persepsi-Remaja-Terhadap-Kelompok-Teman-SebayaDengan-Kecenderungan-Kenakalan-Remaja) Diunduh pada 22 Maret 2019.

Hasanah, Putri Rizki Ridlotun. 2018. Analisis Sosiometri Kepemimpinan Kepala Sekolah. Thesis. Magister Administrasi Pendidikan Sekolah Pasca Sarjana Universitas Muhammadiyah Surakarta

Nita, Rahma Wira dan Ahmad Zaini.. 2017. Analisis Aplikasi Sosiometri untuk Pengungkapan Interpersonal Skill (Solusi Yang Ditawarkan Menuju Profesionalisme Guru Bk). Laporan Hasil Penelitian. Dimuat dalam Proceeding Seminar dan Lokakarya Nasional Revitalisasi Laboratorium dan Jurnal Ilmiah dalam Implementasi Kurikulum Bimbingan dan Konseling Berbasis KKNI, 4 - 6 Agustus 2017, Malang, Jawa Timur, Indonesia.

Santrock, John W. 2007. Remaja. Jakarta: Erlangga

Septi Arnita. 2013. Menjalin Hubungan Dengan Teman Sebaya. Diakses dari http://septiarnita.blogspot.co.id/2013/06/menjalin-hubungan-dengan-teman-sebaya_6.html. Diunduh pada 22 Maret 2019.

Sukartini, Sri Patmah. (2003). Model Konseling Keterampilan Hidup untuk Mengembangkan Dimensi Kendali Pribadi yang Tegar. Disertasi Doktor pada PPS UPI Bandung: tidak diterbitkan.

Sukri, Made. 2018. Mengatasi Permasalahan dan Peningkatan Prestasi Belajar IPA Melalui Konseling Eklektif dengan Perilaku Attending pada Siswa Kelas VIII B2 Semester Ganjil Tahun Pelajaran 2018/2019 SMP Negeri 6 Singaraja. Laporan Hasil Penelitian.

Sukri, Made. 2019. Mengatasi Permasalahan dan Peningkatan Prestasi Belajar IPA Melalui Konseling Eklektif dengan Perilaku Attending pada Siswa Kelas VIII B2 Semester Ganjil Tahun Pelajaran 2018/2019 SMP Negeri 6 Singaraja. Artikel Ilmiah yang dimuat dalam Jurnal IKA Undiksha, Vol.17. No. 1. Maret 2019. ISSN 1829-5282. Hal.1-9.

Surya, Moh (1988), Dasar- Dasar Konseling Pendidikan (Konsep dan Teori),Yogyakarta: Kota Kembang 
Woolfolk, Anita. 2009. Educational Psychology Active Learning. Edisi Kesepuluh. Yogyakarta: Pustaka Pelajar.

Yuanita, Sari. 2011. Fenomena dan Tantangan Remaja Menjelang Dewasa. Yogyakarta: Brilliant Books.

Yusuf, Syamsu LN. 2002. Psikologi Perkembangan Anak dan Remaja. Bandung: PT Remaja Rosdakarya. 